\title{
高圧アルゴン雾囲気中におけるアーク溶接*
}

\author{
管 泰 雄**, 蓮 井渖**
}

\section{On Arc Welding in High Pressure Argon Atmosphere*}

\author{
by Yasuo Suga**, Atsushi Hasui**
}

Characteristics and behavior of tungsten arc and feasibility of arc welding of mild steels were investigated in the pressure range from 0 to $5 \mathrm{MPa}$ (gauge). As the cathode, $2 \%$ thoriated tungsten of $4 \mathrm{~mm}$ in diameter and of $30^{\circ}$ in vertex angle was used.

Results obtained are summarized as follows:

(1) Arc voltage increases with increasing pressure. However, $V_{A}+V_{K}$ decreases a little with increasing pressure from $0 \mathrm{MPa}$ to $0.5 \mathrm{MPa}$. It shows about $7.3 \mathrm{~V}$ constantly over $0.5 \mathrm{MPa}$.

(2) Diameter and half width of arc decreases and the current density in centre of arc increases considerably with increasing pressure.

(3) The area of cathode spot decreases and therefore it concentrates at the tip of tungsten with increasing pressure. As the result, the erosion of tungsten tips increases.

(4) In constant welding current, the depth of penetration of mild steel increases with increasing pressure. Therefore, the optimum current for penetration welding of thin mild steel plate decreases with pressure.

(5) Relatively sound penetration welds of mild steel plates of 2 and $3.2 \mathrm{~mm}$ in thickness can be obtained under pressure range up to $5 \mathrm{MPa}$. However, the meandering bead was often obtained by the fluctuated arc over $2 \mathrm{MPa}$.

(6) Welded joints obtained under pressure range of up to $5 \mathrm{MPa}$ have sufficient tensile strength and Charpy impact value.

Key Words: High pressure, $5 \mathrm{MPa}$, Argon atmosphere, Underwater dry welding, Characteristics of arc, Current density, Hyperbaric welding, Erosion of cathode

\section{1. 緒}

海洋開発に関連して, 海洋棈造物の構築及び補修の手 段としての水中溶接法に関する研究が各方面で行なわれ ており，種々の溶接法が提案されている゙。.とうした状 況の下で，比較的実用性の高い溶接法の一つとして，溶 ·接籄所をチャソバーで覆い，その中の水を排除し，周团 と等しい压力の気中でアーク溶接を行なう Hyperbaric 溶接法と称する乾式水中溶接法が注目されている2，本 法は比較的簡便で経済性・実用性に優れている反面, 高 水深での作羍では需围気压力が上昇するため，圧力の溶 接現象ならびに溶接結果への影響が極めて大きい之いう 問題を有する ${ }^{1-4)}$. そのため, 近年, アーク溶接に及洣す 任力の影響に関する研究が行なわれつつある ${ }^{5-10)}$. そこ で，著者らは水深 $500 \mathrm{~m}$ までの海中におりる乾式水中 アーク溶接を想定して， $5 \mathrm{MPa}$ （gauge）まで加圧可能 な小形王力容器を製作し, 主として溶接アーク現象に及 ぽす玨力の影響について寒験的検封を加えた。本論文で は，高圧アルゴン霉囲気中におりる非消耗電極を用いた 溶接アークの特性及び性状に及ぽす圧力の影響及び軟銅 板の溶接性ならびに得られた溶接継手の機械的性質等に ついて若于の检討を加えた結果について報告する。

\section{2. 実験装置及ひ供試材料}

Fig. 1 亿実験装置の構成の概略を示す．圧力容器は内

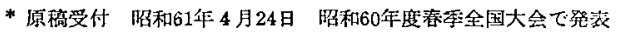

**正员殿応義望大等 Member, Keio University

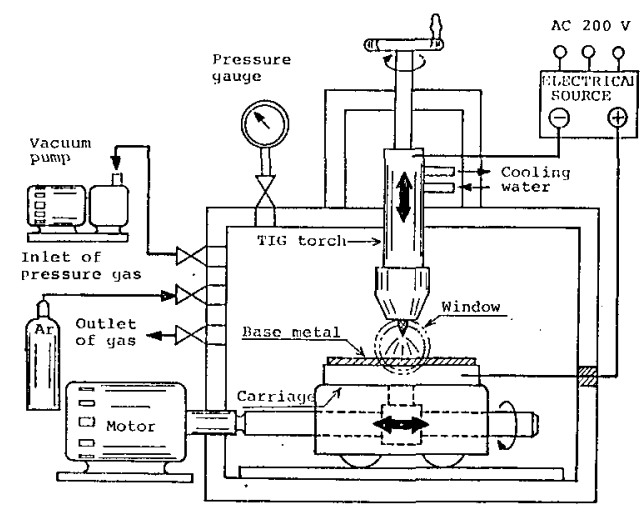

Fig. 1 Arrangement of equipment

容積約 $4000 \mathrm{~cm}^{3}(4 l)$ であり, ゲージ圧で $5 \mathrm{MPa}$ まで 加圧可能である. 容器内には, 走行台車及び外部のハン ドル操作により上下に移動できる水冷式の TIG 溶接卜 ーチが設置されている。なお，アーク現象は左有の空か ら直接筧察するととができる，溶接電源には，垂下特性 の直流電源を使用し，楆性は棒マイナス（DCEN）とし た. 陰極には直径 $4 \mathrm{~mm}$ の 2 \%トリア入りタングステ ンを用い，その先端角度は $30^{\circ}$ ，先端の平坦部直径は約 $0.5 \mathrm{~mm}$ とした. アーク特性に関する実験においては, 陽極として $\phi 60 \times 80 \mathrm{~mm}$ の熱容量の大きい銅ブロック を使用し，その過熱防此のため，アーク発生時間は 1〜2 
$\min$ に限定した. 溶接は, まず圧力容器内を真空ポンプ で約 $133 \mathrm{~Pa}$ (1 torr) まで堿圧し, 純アルゴンガスで所 定圧力まで加圧した後, 母材・陰極間距離を $0.25 \mathrm{~mm}$ として高周波放電を用いてアークを発生させ，その後所 定のアーク長に調節してから行なった。 なお，シールド ガスは用いていない。

用いた供試材料は, 厚さ 2 及び $3.2 \mathrm{~mm}$ の SPCC 鋼 板ならびに厚さ $6 \mathrm{~mm}$ の SM $41 \mathrm{~A}$ 鋼板である. Table 1 K，それらの化学成分分析結果を示す.

\section{3. 溶接アーク現象に及ぼす雾囲気圧力の影響}

\section{1 アークの特性}

Fig. 2 は, タングステン陰極と銅陽極との間に発生さ せたアークを直接観察したあので, アーク長 $l=3 \mathrm{~mm}$, 溶接電流 $I=100 \mathrm{~A}$ とした場合のアークの写真を示して いる. $0 \mathrm{MPa}$ におけるアークは, 比較的輝度が低く, 陽 極に向かって大きく広がった裙野の広い形状を示してい る. また陰極点は, 陰極先端部から上方約 $1 \mathrm{~mm}$ 程度の

Table 1 Chemical compositions of base metals (\%)

\begin{tabular}{|c|c|c|c|c|c|c|}
\hline Material & $\begin{array}{l}\text { Thickness of } \\
\text { base metal } \\
\text { ( mm ) }\end{array}$ & c & si & $\mathrm{Mn}$ & P & s \\
\hline SPCC & 2.0 & $\begin{array}{l}0.044 \\
-0.049\end{array}$ & 0.007 & 0.22 & 0.027 & 0.013 \\
\hline SPCC & 3.2 & $\begin{array}{l}0.046 \\
-0.049\end{array}$ & 0.031 & 0.32 & 0.013 & 0.015 \\
\hline SM41A & 6.0 & 0.12 & 0.22 & 0.64 & 0.018 & 0.018 \\
\hline
\end{tabular}

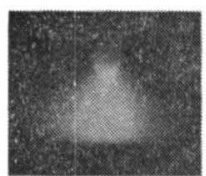

(A) $0 \mathrm{MPa}$

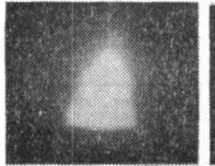

(D) $3 \mathrm{MPa}$

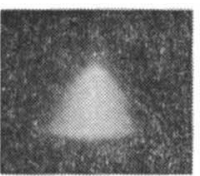

(B) $1 \mathrm{MPa}$

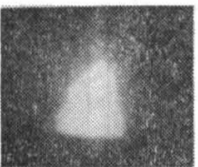

(F) $4 \mathrm{MPa}$

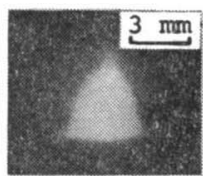

(C) $2 \mathrm{MPa}$

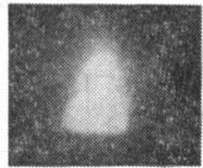

(E) $5 \mathrm{MPa}$
Fig. 2 Effect of ambient pressure on arc shape (Arc length: $3 \mathrm{~mm}$ )
広範网にほぼ均一に分布し, いわゆるノーマルモード

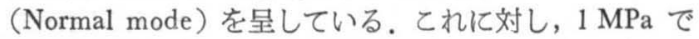
は,アーク径が減少してその輝度が増大し, 陰極点む夕 ングステン先端部に集中したカソードスポットモード (Cathode spot mode) を呈している. との様な傾向は圧 力の上昇と共に顕著となり, 特に, $3 \mathrm{MPa}$ 以上では, 陰 極点がタングステン先端平面のエッジ部に集中している 様子が観察される，との結果，高圧下では高密度の電流 によりタングステン陰極先端が過熱して, その消耗が増 大する傾向が認められた，また，院極点形成箇所が先端 部の円周エッジ部に固定されることによってアークが偏 心し, その結果, アークの指向性が失われる傾向が認め られた。

Fig. 3 は, それぞれ (A) 直流アークの静的電流一電圧 特性, (B) アーク長一電圧特性及ぴ (C) アーク電圧と 圧力との関係をまとめて示したあのである。図(A)は, アーク長を $2 \mathrm{~mm}$ とし, 種々の圧力下でアークを発生 した場合の $I-V_{a}$ の関係を示したあのであるが, P の上 昇と共に $V_{a}$ が増大しているとと, また $V_{a}$ の極小值が 低電流側に移行していることがわかる. 特に, P が 0 $\mathrm{MPa}$ では $150 \mathrm{~A}$ まで, $1 \mathrm{MPa}$ では $50 \mathrm{~A}$ までの電流範 囲において負性抵抗特性を呈するが，圧力が $2 \mathrm{MPa}$ 以 上においては, 特性曲線は単調増加を示している。

図(B)は， $I=100 \mathrm{~A}$ とした場合の $l-V_{a}$ 特性を示したあ ので, いずれの圧力下においても $l$ の増大と共に $V_{a}$ が 上昇しており, その上昇傾向は, 圧力の増大と共に著し く大となることがわかる。なお， $V_{a}$ は $l$ に必ずしあ比 例しておらず， $l$ の増大と共に若于 $V_{a}$ の上昇傾向が娍 少している.

図(c)は, $I=100 \mathrm{~A}, l=2 \mathrm{~mm}$ とした場合の圧力 $\mathrm{P}$ とア 一ク電圧 $V_{a}$ との関係を示したものであり, 図中に陽極 電圧降下と陰極電圧降下の和 $V_{A}+V_{K}$ の值む示してあ る.とこで, $V_{A}+V_{K}$ は, 電流を一定に保持したまま陽 極と陰極を接近させつつ電圧をペンレコーダに記録し， 短絡する直前の電圧を実測して求めた。なお, 本実験条 件の下では，銅陽極の溶融はほとんど認められなかっ た. 図より, $V_{a}$ は圧力の上昇と共に増大しており, たと えば, $0 \mathrm{MPa}$ における $V_{a}$ は約 $10.3 \mathrm{~V}$ であるのに対 し, $5 \mathrm{MPa}$ では $25 \mathrm{~V}$ に達している。乙れは, 圧力の上昇 に伴う雲囲気ガスの密度及び熱伝導率の上昇により, ア

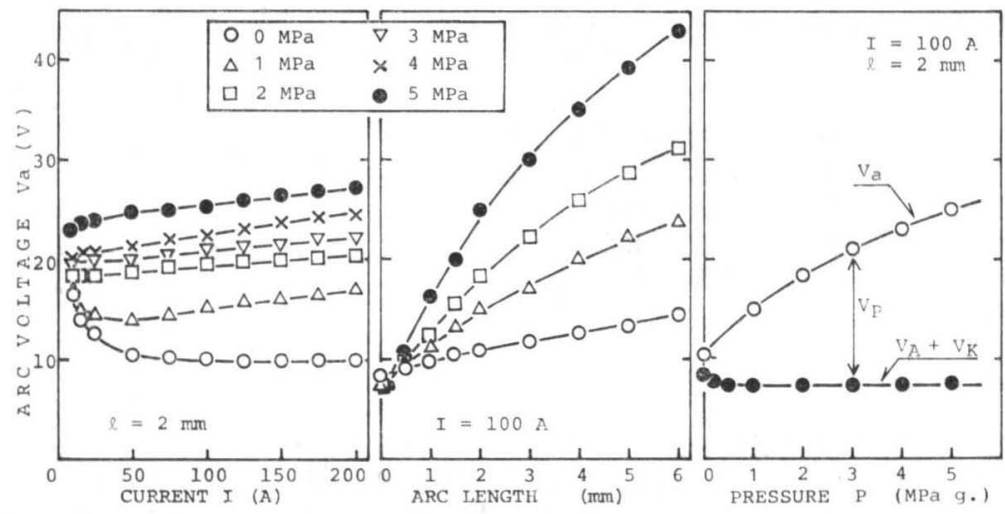

(A) I-Va characteristics (B) l-Va characteristics (C) P-Va characteristics

Fig. 3 Effect of ambient pressure on characteristics of arc 
一クが熱ピンチ効果を受けて緊縮し，その結果電圧が上 显したものと解橎される。一方， $V_{A}+V_{K}$ は，正力 0 $\mathrm{MPa}$ 亿おいて約 $8.3 \mathrm{~V}$ を示しているが, 死力の上昇之 共に低下し，0.2 MPa では約 $7.8 \mathrm{~V}, 0.5 \mathrm{MPa}$ では7.3 $\mathrm{V}$ である。なお，0.5 MPa 以上ではほぽ一定の值を示し た。 $V_{A}+V_{K}$ の值に及ほすす圧力の影響については，二， 三の報告 ${ }^{5}$.10) があるが，玨力の上昇と共にその值が上昇 するという説と逆に低下するという説に分かれている。 これは，電極を短絡する直前の $V_{a}$ を直接湘定する方法 によるおのよ $l-V_{a}$ 曲線加ら $l=0$ におりる $V_{a}$ 值を外 擂して求める方法との測定法の違いにより生じたものと 判断される，後者では曲線部分を直線で外掅することに よる誤差を生じる可能性が高く，したがって, 著者らが 用いた短絡法による実測において昰当な值が得られてい るあのと考えられる。なお，圧力の上昇に伴って $V_{A}+$ $V_{K}$ が低下する理由については, 压力の上昇と共にア一 クの陰極点が陰極の先端に集中してその温度が著しく上 昇し，その結果，熱陰極加らの電子放出加上り容易に行 なわれ， $V_{K}$ が低下したためと考えられる。しかし，乙 の点に関しては，今後の検討を要するあのと思われる。

以上の結果より， $V_{A}+V_{E}$ 值は圧力に関係せずほばー 定であり，圧力の上昇に伴うアーク電圧 $V_{a}$ の上昇はア 一ク柱電圧降下 $\left\{V_{p}=V_{a}-\left(V_{A}+V_{K}\right)\right]$ によるあのであ ることが確認された。今，得られた $V_{p}$ よりアーク柱の 電位傾度 $\left(V_{g}=V_{p} / l\right)$ と王力との関係救めると, Fig. 4 が得られる。図より，圧力の上䒜と共に $V_{g}$ は著しく 増大しており，たとえば， $l=2 \mathrm{~mm}$ の場合， $0 \mathrm{MPa}$ にお ける $V_{g}$ は約 $0.95 \mathrm{~V} / \mathrm{mm}$ であるのに対して, $5 \mathrm{MPa} に$ おけるそれは約 $8.9 \mathrm{~V} / \mathrm{mm}$ であり㷙者の約 9.5 倍に達 している.

Allum は，乙の電位傾度 $V_{g}$ が圧力の平方根化比例す るという関係を見い出し，との関係より，アルゴン雾囲

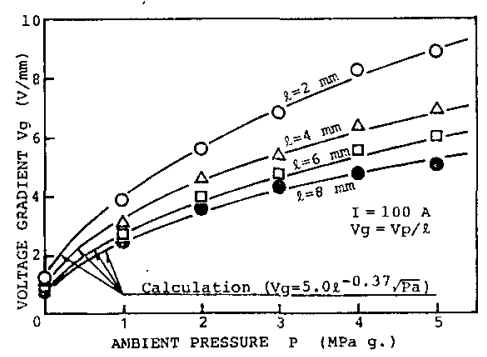

Fig. 4 Effect of ambient pressure on voltage gradient of arc
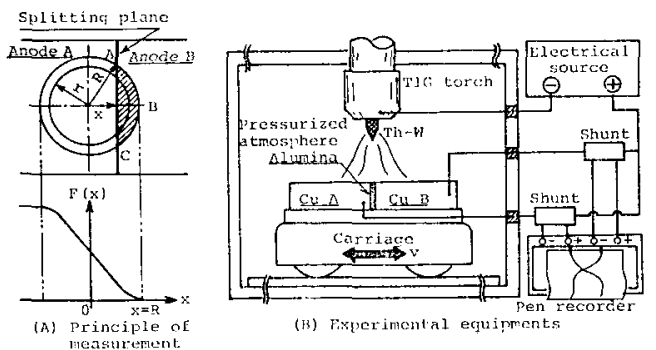

(B) Firuerinontal equipments

Fig. 5 Principle and experinental equipments for measuring current density of arc
気中のアーク電圧を推定するための実験式を提案してい $ろ^{7,8)}$. この式の压力単位を $\mathrm{MPa}$ に换算して示すと次 式が得られる。

$$
V_{a}=8+2.5 l \sqrt{\mathrm{P}_{a}}
$$

ここで, $\mathrm{P}_{a}$ は雰团気絶対圧力 ( $\mathrm{MPa}$ abs. )， $\mathrm{V}_{a}$ はアー ク電压 $(V), l$ はアーク長 $(\mathrm{mm})$ である.

これに対し，著者らの测定結果を整理すると， $V_{g}, P_{a}$ ， $l$ の間に $V_{g} \propto \sqrt{\mathrm{P}_{a}}$ 及び $V_{g} \propto l^{-0.37}$ の関係が得られ, これより次式が求まる。

$$
V_{g}=5.0 l^{-0.37} \sqrt{P_{a}}
$$

本実験式より求めた优を Fig. 4 中に実線で示してある が，図より計算值上実测值が良好な一致を示していると とがわかる。とれよりアーク電压 $V_{a}$ を推定する式を求 めると，次式が得られる。

$$
V_{a}=V_{0}+5.0 l^{0.63} \sqrt{P_{a}}
$$

但し， $V_{0}=V_{A}+V_{K}$ であり，その值はたとえば $V_{0} \div 8.3 \mathrm{~V}$ $\left(P_{a}=0.1 \mathrm{MPa}\right.$ abs. $), V_{0} \doteqdot 7.3 \mathrm{~V}\left(P_{a} \geq 0.4 \mathrm{MPa}\right.$ abs. $)$ て ある.なお，本式の適用範囲は $0.1 \leqq P_{\alpha} \leqq 5.1 \mathrm{MPa}$ abs., $1.5 \leqq l \leqq 8 \mathrm{~mm}$ である.

\section{2 アークの電流密度分布の測定}

アークの陽栖におりる電流密度分布に及ぽす雾团気压 力の影響について検討する。今，陽極表面においてア一 クの電流密度分布が完全に軸対称であるとする．アーク 中心から任意の半径 $r$ におりる点の電流密度を $j(r)$ 之 すると, Fig. 5(A)に示すように, $r \geq R$ において $j(r)=0$ と仮定するならば，図中 A B C すなわち晹極 $B$ K流 れる電流值 $I(x)$ は，

$$
I(x)=2 \int_{x}^{R} j(r) \cos ^{-1}(x / r) r d r
$$

で与えられる。ここで $x$ は，アークの中心からの分割線 までの距離である。(4)式を $x$ に関して微分すると, 分割 線上におりる需流值の積分值 $Q(x)$ が求まる.

$$
Q(x)=2 \int_{x}^{R} \frac{j(r) r d r}{\left(r^{2}-x^{2}\right)^{1 / 2}}
$$

(5)式は Abel の稫分方程式として知られており，その解 は次式で与えられる。

$$
f(r)=\frac{1}{\pi} \int_{r}^{R} \frac{Q^{\prime}(x) d x}{\left(x^{2}-r^{2}\right)^{1 / 2}}
$$

O.H. Nestor ら ${ }^{11)}$ は, $I(x)$ データから $j(r)$ を求めるた めに半径 $R$ の円を幅 $a$ の $2 n$ 個の短冊状部分に分割し て数值計算を行ない, $I(x)$ と $j(r)$ の換算係数 $G_{k, n}$ を 求めている. 本実験では，ての Nestor らの係数を用い て計算を行なった。

Fig. 5(B) は，陽極における電流密度分布を測定するた めの装置の概略を示したもので，愿さ $10 \mathrm{~mm} の \mathrm{~A} ， \mathrm{~B}$ 2 個の銅ブロック(一方のブロックの接触面にアルミナ を厚さ約 $0.2 \mathrm{~mm}$ 浴射して他方之絶縁している）を突合 わせて，走行台車に固定してある。まず，片側の銅ブロ ックでアークを発生し，それを維持しつつ，台車を速度 $v=6 \mathrm{~cm} / \mathrm{min}$ で移動して，乙のときの A 及び B ブロッ クに流れる電流の変化をそれぞれペンレコーダによって 記録するすのである。

Fig. 6 はアルゴン雲围気中において $I=100 \mathrm{~A}, l=3$ $\mathrm{mm}$ とした場合の電流の変化を記録した\}才シグラムの 一例定したあのである。このような電流值の変化よ り，数值計算してアークの電流密度分乍定求めた。

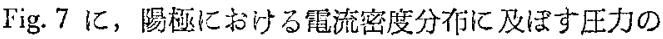




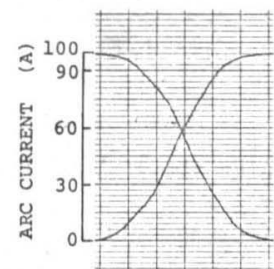

(A) $0 \mathrm{MPa}$

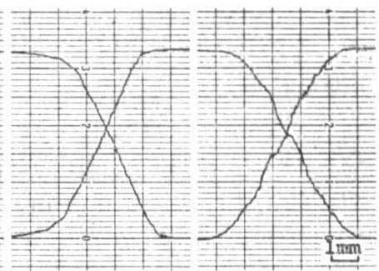

(B) $2 \mathrm{MPa}$
(C) $5 \cdot \mathrm{MPa}$
Fig. 6 Change of arc current in current density test

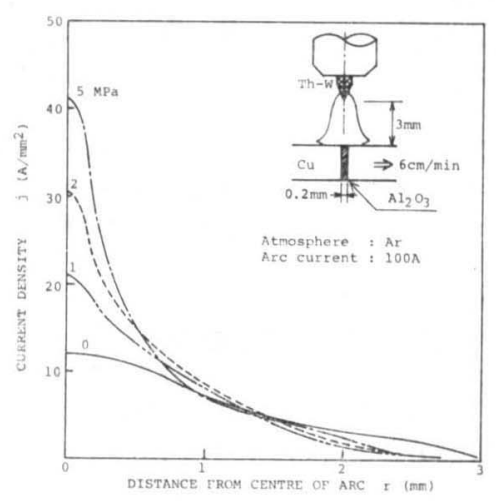

Fig. 7 Effect of ambient pressure on current density distributions of arc

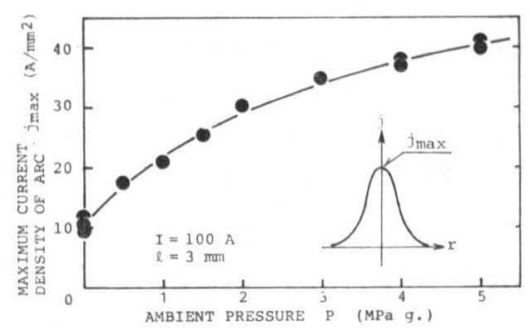

Fig. 8 Effect of ambient pressure on maximum current density of arc

影響を示す. $0 \mathrm{MPa}$ におけるアークの電流密度は, 比較 的平坦な分布を示しているが, 圧力の上昇と共にアーク 中心部の電流密度が著しく増加している. これは圧力の 上昇に伴う熱ピンチ効果によってアークが緊縮し, その 中心部の電流密度が増大したものと考えられる。

Fig. 8 に, 電流密度分布より得られたアーク中心にお ける最大電流密度 $j$ max に及ぼす雲囲気圧力の影響をま とめて示す. 圧力 $0 \mathrm{MPa}$ における $j$ max は約 $10 \mathrm{~A} /$ $\mathrm{mm}^{2}$ であるのに対し, $1 \mathrm{MPa}$ ではその 2 倍の約 $20 \mathrm{~A} /$ $\mathrm{mm}^{2}$ であり, $5 \mathrm{MPa}$ におけるそれは約 $40 \mathrm{~A} / \mathrm{mm}^{2}$ に達 している.したがって, アークの中心温度はかなり上昇 しているはずで, アークの直接観察の結果その輝度が著 しく増大していたのはこのためと考えられる.

Fig. 9 に, 陽極面上におけるアークの直径 $d$ 及び半值 幅 $d_{h}$ を測定した結果を示す. ここで, 半值幅 $d_{h}$ とは アークの電流密度分布曲線において $j=j$ max $/ 2$ における 直径 $d$ の值である. 図より, 圧力が 0 から $5 \mathrm{MPa}$ に上 昇すると, $d$ は約 $6 \mathrm{~mm}$ 加ら $4.5 \mathrm{~mm}$ に, $d_{\boldsymbol{h}}$ は, 2.1

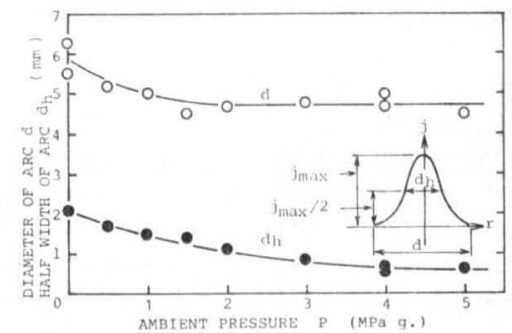

Fig. 9 Effect of ambient pressure on diameter (d) and half width $\left(\mathrm{d}_{\boldsymbol{h}}\right)$ of arc

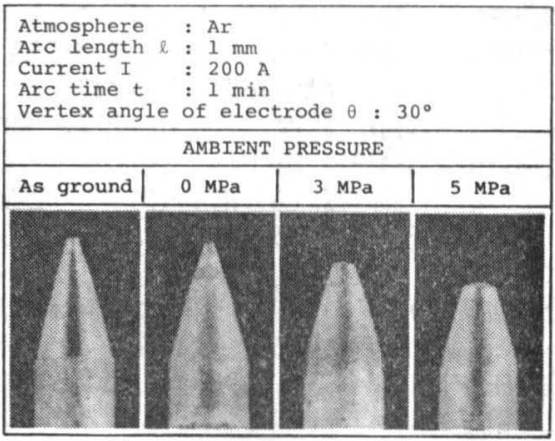

Fig. 10 Effect of arc current on erosion of electrode tips

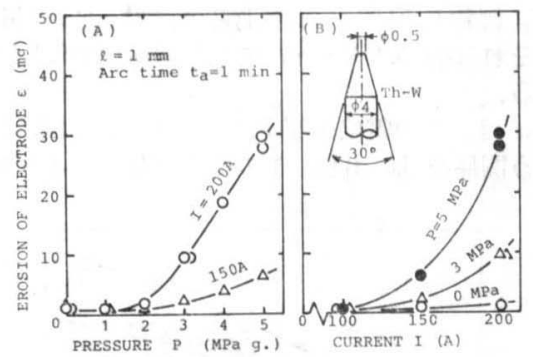

Fig. 11 Effects of ambient pressure and arc current on erosion of electrodes

$\mathrm{mm}$ から $0.6 \mathrm{~mm}$ まで減少しており, 圧力の上昇と共 にアークが緊縮していることが定量的に確認される。な お, $2 \mathrm{MPa}$ 以下の比較的低圧力領域では, $d$ 及び $d_{h}$ は 圧力の上昇と共に急激に減少するが, $2 \mathrm{MPa}$ 以上では影 著な減少傾向は認められない。乙の結果は,アークの観 察結果とほほ対応している。

以上の結果より, 圧力の上昇と共にアークが緊縮して その径が減少し，アーク中心部の電流密度が著しく増大 することが定量的に裹付けられた．

\section{3 タングステン旡極の消耗}

タングステン陰極の消耗特性は, 高圧雲囲気中での溶 接性を支配する重要な因子である12).そこで, 溶接電流 $I=200 \mathrm{~A}$, 初期のアーク長 $l=1 \mathrm{~mm}$, アーク時間を 1 min 亡した場合のタングステン除極の消耗に及ぼす䨌井 気圧力の影響について検討した. Fig. 10 は, その結果 を示したもので, 写真より圧力の上昇と共にタングステ ン陰極先端の消耗量が増加しているととがわかる. Fig. 11(A)，(B)はそれぞれ，陰極の消耗量 $\varepsilon$ 亿及ぼす圧力及 

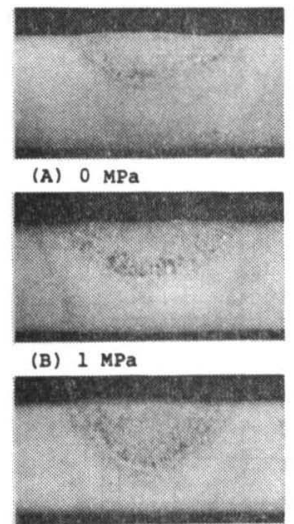

(C) $2 \mathrm{MPa}$

Fig. 12 Effect of ambient pressure on macrostructures of welds $(I=200 \mathrm{~A})$
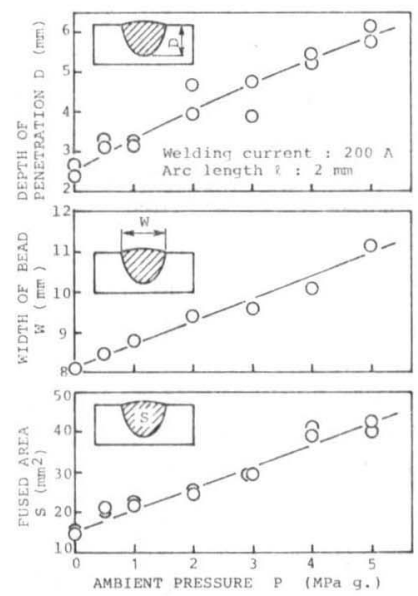

Fig. 13 Effect of ambient pressure on weld bead shapes

び溶接電流の影響を示したものである。なお， $\varepsilon$ は央験 前後におけるタングステンの質量差より求めた。図よ り, 本実験条件の下では, 压力が約 $2 \mathrm{MPa}$ を超えると 急速に $\varepsilon$ が増加する傾向が見られる。 また， 3 及び 5 $\mathrm{MPa}$ の下では, $\varepsilon$ は電流の増加と共に増大しているが, 特に $150 \mathrm{~A}$ を超えるとその増加傾向が顕著となる. これ は，圧力の上昇と共に電流が陰極先端に集中して局部的 な過熱域を生じ, ある臨界電流を超えたときにその一部 が溶融して消耗量が増加したあのと考えられる.

\section{4. 軟鋼板の溶接結果に及ぼす雾囲気圧力の 影響}

\section{1 軟鋼溶接部の溶込み形状}

Fig. 12 は, 板厚 $6 \mathrm{~mm}$ の SM $41 \mathrm{~A}$ 鎆板を溶接電流 $I=200 \mathrm{~A}$, 溶接速度 $v=20 \mathrm{~cm} / \mathrm{min}$, 見加けのアーク長 $l=1.5 \mathrm{~mm}$ として, 種々の压力下でビードオンプレー ト溶接した場合の溶接部の横断面マクロ組織を示した屯 のであり，Fig. 13 は，溶接部の溶込み形状を測定した 結果を示したあのである。図より，圧力の上昇と共に溶 込み深さ $D$, ビード幅 $W$ 及び溶込み面積 $S$ はいずれ も増大している. これは, 前述したように圧力の上昇と

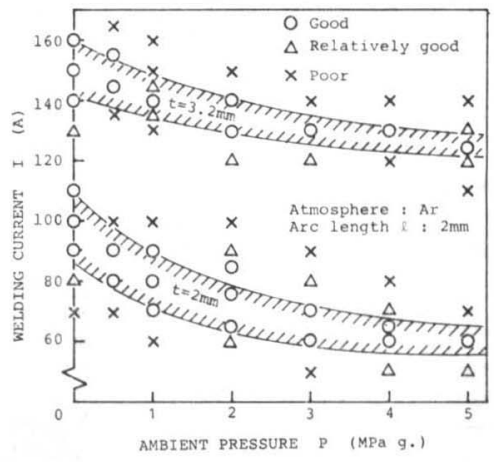

Fig. 14 Effects of ambient pressure and welding current on results of penetration welding

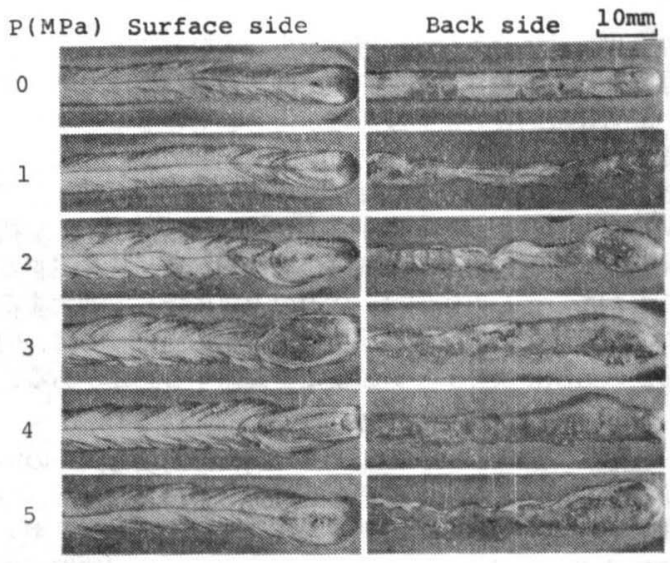

Fig. 15 Effect of ambient pressure on appearances of welds $(t=3.2 \mathrm{~mm})$

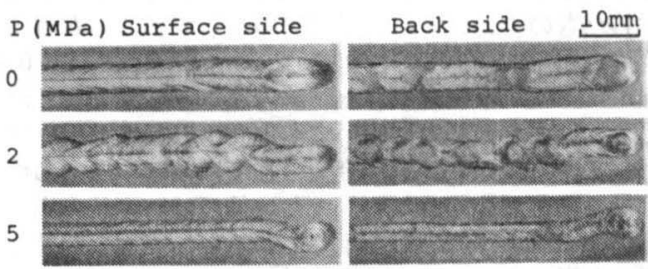

Fig. 16 Effect of ambient pressure on appearances of welds $(t=2 \mathrm{~mm})$

共にアーク電圧が上昇して鋼板に供給される溶接入熱が 増加し, 結果的に, 溶融量が増大したものと考えられ る。なお，溶込み比 $D / W$ を計算すると, $0 \mathrm{MPa}$ では約 0.3 が, $5 \mathrm{MPa}$ では約 0.5 が得られ, 压力の上昇と共に若 于ビード幅に比へて溶込みの深い形状の溶接が得られて いることがわかる.

\section{2 薄鋼板の裹波溶接}

Fig. 14 は，0から $5 \mathrm{MPa}$ までの压力下で, 板厚3.2及 び $2 \mathrm{~mm}$ の SPCC 鋼板に種々の溶接電流を用いて裏波 溶接した場合の適正な溶接が得られる電流の範囲と圧力 の関係を，また Fig. 15 及び Fig. 16 は，適正溶接電流を 用いて得られた裹波溶接部の表面ビード及び裹波ビード の外観を示したものである。なお，溶接速度 $v$ は $20 \mathrm{~cm}$ $/ \mathrm{min}$ とし,アーク長 $l$ は $2 \mathrm{~mm}$ とした. 図より, 压力 
Table 2 Mechanical properties of welds

\begin{tabular}{|c|c|c|c|c|c|c|c|}
\hline \multirow{2}{*}{$\begin{array}{l}\text { Thiokness } \\
\text { of } \\
\text { base metal } \\
t(\mathrm{~mm})\end{array}$} & \multirow{2}{*}{$\begin{array}{l}\text { Ambient } \\
\text { pressure } \\
\text { P (MPa) }\end{array}$} & \multicolumn{3}{|c|}{ welded joint } & \multicolumn{3}{|c|}{ Weld metal } \\
\hline & & $\begin{array}{l}\text { Tensile } \\
\text { strength } \\
\text { (MPa) }\end{array}$ & $\begin{array}{c}\text { Elongat ion } \\
\text { (Gt=40 } 10 \mathrm{~min}) \\
\text { (8) }\end{array}$ & $\begin{array}{l}\text { Location } \\
\text { of } \\
\text { fracture }\end{array}$ & $\begin{array}{l}\text { Pensile } \\
\text { strength } \\
\text { (MPA) }\end{array}$ & $\mid \begin{array}{c}\text { Joint } \\
\text { effigiency } \\
(\ell)\end{array}$ & $\begin{array}{l}\text { E'longation } \\
\text { (GL=2Gm) } \\
\text { (8) }\end{array}$ \\
\hline \multirow[t]{2}{*}{2} & $\begin{array}{l}0 \\
1 \\
2 \\
3 \\
4 \\
5 \\
\end{array}$ & $\begin{array}{l}319 \\
318 \\
315 \\
326 \\
315 \\
328 \\
\end{array}$ & $\begin{array}{l}18 \\
18 \\
17 \\
22 \\
24 \\
24 \\
\end{array}$ & $\begin{array}{l}\text { Base metal } \\
\text { Base metal } \\
\text { Base metal } \\
\text { Base metal } \\
\text { Base metal }\end{array}$ & \begin{tabular}{|l}
494 \\
518 \\
524 \\
516 \\
542 \\
544 \\
\end{tabular} & $\begin{array}{l}126 \\
132 \\
133 \\
131 \\
138 \\
138 \\
\end{array}$ & $\begin{array}{r}9 \\
13 \\
10 \\
14 \\
13 \\
14\end{array}$ \\
\hline & Base metal & 315 & 43 & $=$ & 393 & - & 13 \\
\hline \multirow[t]{2}{*}{3.2} & \begin{tabular}{|l|}
0 \\
1 \\
2 \\
3 \\
4 \\
5
\end{tabular} & $\begin{array}{l}348 \\
356 \\
348 \\
349 \\
352 \\
359\end{array}$ & $\begin{array}{l}23 \\
16 \\
21 \\
27 \\
27 \\
27 \\
\end{array}$ & $\begin{array}{l}\text { Base metal } \\
\text { Base metal } \\
\text { Basc metal } \\
\text { Base metal } \\
\text { Base metal } \\
\text { Base metal }\end{array}$ & $\begin{array}{l}529 \\
539 \\
553 \\
507 \\
533 \\
566 \\
\end{array}$ & $\begin{array}{l}124 \\
127 \\
130 \\
120 \\
125 \\
133 \\
\end{array}$ & $\begin{array}{l}15 \\
12 \\
12 \\
12 \\
13 \\
13 \\
\end{array}$ \\
\hline & Base netal & 342 & 44 & - & 424 & - & 17 \\
\hline
\end{tabular}

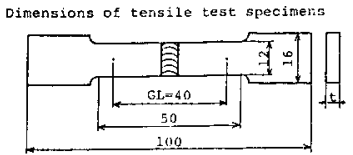

(A) As-welced joint

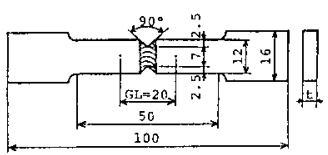

(B) Wela metal
の上昇と共に適正な電流值が減少しているとと，また， 写真より，アルゴン雺囲気中では，いずれの圧力下に扤 いても此較的良好な旁波溶接が得られていることがわか る.なお，X線透過武験の結果，溶接部には気孔などの 溶接欠陷の発生は認められなかった。 また，圧力が 2 $\mathrm{MPa}$ 上上では，アークの指向﨡が失わ机てアークが摇 勘し，ビードに数 $\mathrm{mm}$ 間隔の周期的なうねりを生ずる ことがある。乙の傾向は，压力の上暈に伴って増大する ため, 高压下でのアーク溶接の染用化住当たっては, 何 らかの方法によりアークの安定を確保する必要がある.

\section{3 溶接継手の機橪的性質}

板厚 3.2 及び $2 \mathrm{~mm}$ の $\mathrm{SPCC}$ 鋼板を前項之同一の溶 接条件を用いて 1 パス突合わせ溶接して得られた継手の 機械的性質を調べた。開先形状はＩ形としルートギャ ップは $0 \mathrm{~mm}$ とした. Table $2 に$, 突合わせ溶接継手の 引張武験結果を示す。用いた引張武験片の形状寸法は表 の下に示してある。表中左㯗は平行試験片による結果を

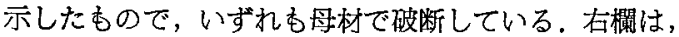
溶接金属部飞角度 $90^{\circ}$, 深さ $2.5 \mathrm{~mm}$, 先端半径 0.25 mm の V ノッチを入れた武験片による結果を示したも ので，いずれの圧力においても $100 \%$ 以上の継手効率を 有している。なお，溶接金属の強度に及ぽす压力の影蝆 はほとんど認められない。 また，伸びはいずれの場合も 母材のそれより低い值を示しているが，実用上問題ない あのと䓔えられる。

Table $3 に$, 溶接継手のシャルピー衙撃試験結果を示 す。用いた武験片の寸法は表の下に図示してある。な

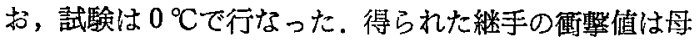
材のそれにやや劣りはするすのの，いずれあ 130〜145 $\mathrm{J} / \mathrm{cm}^{2}$ が得られて招り，溶接部は十分な䩗性を有してい るととがわかる。

\section{5. 結}

\section{言} る.

本研究で得られた主な結果は以下のようにまとめられ

(1) 圧力の上䍙に伴い $V_{a}$ は上昇する. $V_{A}+V_{K}$ 値 は, $0 \mathrm{MPa}$ において $8.3 \mathrm{~V}$ であり, 玏の上昇と共に 低下し，0.5 MPa では $7.3 \mathrm{~V}$ となるが，それ以上の圧 カ下ではほほ一定の值を示す。

（2）正力の上昇と共にアーク柱は緊縮して径及び半値
Table 3 Results of Charpy impact tests $\left(0^{\circ} \mathrm{C}\right)$

\begin{tabular}{c|c|c}
\hline $\begin{array}{c}\text { Ambient } \\
\text { pressure }\end{array}$ & \multicolumn{2}{|c|}{$\begin{array}{c}\text { Impact value } \\
\text { (J/cm }{ }^{2} \text { (MPa) }\end{array}$} \\
\cline { 2 - 3 } & $\mathrm{t}=2 \mathrm{~mm}$ & $\mathrm{t}=3.2 \mathrm{~mm}$ \\
\hline 0 & 131 & 135 \\
1 & 133 & 139 \\
2 & 138 & 149 \\
3 & 139 & 141 \\
4 & 132 & 146 \\
5 & 134 & 149 \\
\hline Base meta1 & 149 & 156 \\
\hline
\end{tabular}

Dimensions of specimens

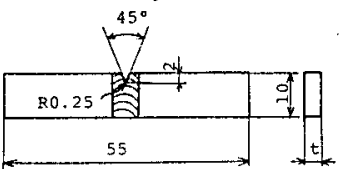

幅は減少する。またアーク中心部の電流密度は増大し， その輝度を著しく增す。陰極点形成域は減少して陰極先 端部に集中し，その結果，タングステン陰極の消耗量は 增加する。

（3）圧力の上昇に伴い，同一の浴接電流值安用いた場 合の溶接部の溶込みは増加する。㐬た薄軟鋼板の豪波溶 接を得るための適正な溶接雪流值は減少する。

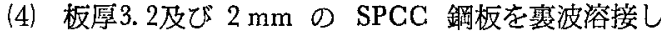
た場合, $5 \mathrm{MPa}$ 以下のいずれの圧力下においてあ比較的 良好な溶接が得られる。但し，压力が $2 \mathrm{MPa}$ 以上では アークの指向性が失われて摇動し，ビードにうねりを生 ずる傾向が認められる。

(5) 雾团気圧力 $5 \mathrm{MPa}$ 以下で得られた溶接継手は， いずれす十分な引張強さ及び衝撃値を有する。

最後に，本实験化協力された東京エレクトロン稝の三 田野好伸君，小西六写真工業侏の駕塚民哉君，古河鉣業 侏の秋元英治君及びオリンパス光学工業侏の今川響君 （いずれも実験当時，慶応義熟大学理工学部の学生）に 感謝の意を表する。

\section{参 考 文 献}

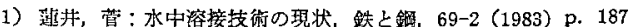

2）尾绮：欧米に怙汁万水中溶接の現状，高温学会誌， 5-5 (1979) p. 202

3) R. P. Lynch, F. J. Pilla : Weld. J., 48 (1969), 3, p. 183

4) H.O. Knagenhjelm : Hyperbaric Welding at $320 \mathrm{MSW}$, Development of Adequate Welding Procedures, IIWCREAU-34-80 (1980)

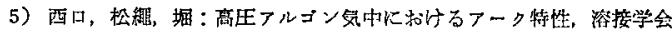
誌，46-8 (1977)，p. 553

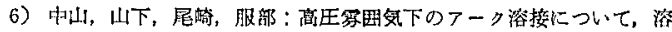
接学会祕，50-8 (1981)，p. 794

7) C.J. Allum: TIG's Underwater Role: Present and future, Weld. Met. Fab., (1982), p. 124-132

8) C. J. Allum : Effect of Pressure on Arcs, Proc. of the Int. Conf. at Trondheim under the auspices of the IIW (1983), p. 171

9) E.L. Burrill, M. L. Levin : The Effect of Pressure on the Welding Arc, Proc. of Int. Conf. on Gas Discharges at London, (1970)

10) O. Djik and den Ouden: The Effect of Pressure on the TIG Welding Process, Proc. of the Int. Conf. at Trondheim under the auspices.nof the IIW (1983), p. 155

11) O. H. Nestor, H. N. Olsen : Numerical Methodes for Reducing Line and Surface Probe Data, SIAM Review, $2-3(1960)$, p. 200

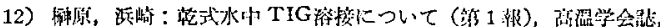
$9-1$ (1983), p. 27 